\title{
Leadership and Meaningful Work in the Public Sector
}

Article in Public Administration Review · November 2013

DOI: $10.1111 /$ puar.12138

CITATIONS

50

2 authors:

\section{Lars Tummers}

Utrecht University

108 PUBLICATIONS 1,047 CITATIONS

SEE PROFILE

Some of the authors of this publication are also working on these related projects:

Project OLDER WORKERS View project

Project

Public Sector Innovation through Collaboration (PSI-CO) View project 


\title{
Leadership and meaningful work in the public sector
}

\author{
Accepted article for Public Administration Review \\ Dr. L.G. (Lars) Tummers*1, Dr. E. (Eva) Knies ${ }^{2}$
}

To be cited as:

Tummers, L.G. \& Knies, E. (2013). Leadership and meaningful work in the public sector. Public Administration Review, 73(6), 859-868.

* Corresponding author: Lars G. Tummers, Tummers@ @sw.eur.nl

${ }^{1}$ Department of Public Administration, Erasmus University Rotterdam, the Netherlands \& Center for the Study of Law \& Society, University of California, Berkeley, The United States ${ }^{2}$ Utrecht School of Governance, Utrecht University Utrecht, the Netherlands 


\begin{abstract}
In the public administration discipline, there have been a number of important studies on leadership. However, here, scholarly inquiry still lags behind related disciplines such as psychology and business administration. This article contributes by analyzing the role public leaders can play in making work more meaningful for their employees, which in turn positively influences employees' job outcomes. More specifically, it analyzes the mediating role of work meaningfulness in the relationships between Leader-Member Exchange (LMX) and organizational commitment, work effort, and work-to-family enrichment. Samples from education, healthcare, and local government are used. Results show firstly that leadership strongly influences work meaningfulness, which in turn influences job outcomes. Secondly, it was found that the impact and extent of leadership and work meaningfulness are higher in healthcare and education than in local government. The results emphasize the importance of leadership and meaningful work in the public sector.
\end{abstract}

\title{
Key words
}

1. Leadership

2. Leader-member exchange

3. Meaningful work

4. Organizational commitment

5. Work effort

6. Work-to-family enrichment 


\section{Introduction}

There have been a number of important studies on leadership in the public administration, and more specifically the public management, discipline (for example Wright and Pandey 2010; Fernandez 2005; Terry 2002; Kim 2002). However, this area of scholarly inquiry still lags behind related disciplines such as business administration and psychology (Trottier, Van Wart, and Wang 2008). Hansen and Villadsen (2010:247) recently concluded that, when compared to other disciplines, "leadership theory has generally received little attention in public management research." In a recent literature review on administrative leadership, Van Wart (2013) is more nuanced, stating that there is substantial development. However, he also noted that "fragmentation and conflicting nomenclature continue to be a problem, but at a more sophisticated level" (2013:13). More specifically, he noted that, for leadership studies in public administration, "well-designed studies would be welcomed by various public sector industries, jurisdictions, and levels of administration" (2013:17).

In response to the call for well-designed leadership studies in public administration, this article focuses on developing a theoretical model relating leadership, the meaning of work, and the resulting job outcomes. This model will be tested using data collected in three public sector settings (healthcare, education, and local government).

In the theoretical model, we build on the well-known notion of leader-member exchange (LMX) that has its roots in social exchange theory (Blau 1964). LMX describes the quality of the relationship between a leader and a member (Graen and Uhl-Bien 1995). LMX research indicates that leaders develop differentiated relationships with their employees. In relationships characterized by low LMX there is essentially an economic exchange between employer and employee (time is exchanged for money). In high quality relationships, mechanisms of reciprocity and social exchange become effective: the leader and the employee 
trust each other, employees feel valued by their supervisor, and effective working relationships develop. In general, high LMX has several important positive job outcomes, such as increased job satisfaction, higher performance, and lower staff turnover (Dulebohn et al. 2012).

However, a piece of the puzzle appears to be missing when examining LMX and its outcomes. As Gerstner and Day (1997:835) observe, although there is evidence that a better employee-supervisor relationship enhances outcomes, this association needs further examination. They suggest examining variables that potentially mediate the relationship. A number of private-sector studies have examined possible mediating mechanisms, and these often use the notion of empowerment. However, results are inconsistent. While Aryee and Chen (2006) found that empowerment mediated the relationship between LMX and job outcomes, Liden et al. (2000:407) failed to find such a relationship. Further, Harris et al. (2009) argued that the relationship between LMX and job outcomes was moderated rather than mediated by psychological empowerment.

This study analyzes work meaningfulness, one of the dimensions of psychological empowerment, as a potential mediator between LMX and its outcomes. This approach seems more promising than using the broad concept of empowerment. The hypothesis tested is that when employees and managers have a good relationship (i.e. high LMX), leaders will provide their employees with greater insight into how the organization works and give them more responsibility. It seems reasonable to expect this to positively influence employees' job experience and the possibility of them making a difference in their work. In turn, one could expect this to have positive outcomes (see also Liden, Wayne, and Sparrowe 2000). In this article, the focus is on two important outcomes inside the work context (organizational commitment and work effort) and one important outcome outside the work context (work-tofamily enrichment). 
This article contributes to the literature by a) focusing on leadership in the public sector using an explicit theoretical model, b) analyzing one specific dimension of empowerment (work meaningfulness) to explain the relationship between LMX and certain outcomes, and c) testing the developed model using three independent public sector samples (drawn from education, healthcare, and local government). The article answers the following research question:

To what extent does the meaningfulness of work mediate the relationship between LMX and outcomes inside the work context (organizational commitment, work effort) and outside the work context (work-to-family enrichment)?

In section 2, we will discuss the theoretical framework. Section 3 describes the method used to test our hypotheses. In section 4, the results are discussed. We conclude by discussing the contribution of this article to the public management literature on leadership (section 5).

\section{Theoretical framework}

\subsection{Background on leadership}

In broad terms, there are two contrasting views on leadership in organizations (Howell and Hall-Merenda 1999). One view is leader-focused and attempts to explain performance by analyzing specific leadership behaviors and linking these directly to outcomes. This view is adopted in theories on transactional and transformational leadership (for a recent public sector example, see Wright and Pandey 2010). The second view is relationship-based, analyzing how leaders interact with their employees. This view is best exemplified by the concept of leader-member exchange (LMX) (Howell and Hall-Merenda 1999:680; Wang et al. 
2005:420). Given the aim of this research, analyzing the role of work meaningfulness in the relationship between LMX and outcomes, the second view is most appropriate.

LMX is defined as the quality of the relationship between a leader (supervisor) and a member (employee) (Graen and Uhl-Bien 1995). Although whether LMX is a management practice or a leadership practice is open to debate (Zaleznik 1977), we follow mainstream LMX research and view LMX as a leadership practice (Graen and Uhl-Bien 1995; Liden, Sparrowe, and Wayne 1997; Dulebohn et al. 2012).

The impact of LMX on several outcomes has been studied extensively. In a metastudy, Gerstner and Day (1997) noted that LMX is positively related to several work outcomes, such as supervision satisfaction, overall satisfaction, and commitment. More recently, Dulebohn et al. (2012) conducted a meta-analysis of 247 studies and found a possible 16 important outcomes of LMX quality, such as behavioral outcomes (lower turnover intention and higher job performance), attitudinal outcomes (higher job satisfaction and organizational commitment), and perceptual outcomes (higher perceived procedural justice and empowerment).

There are some studies that examine the influence of LMX on variables outside of work, such as on work-life balance and work-family arrangements. For instance, Brunetto et al. (2010) found that LMX predicted perceptions of work-family conflicts in particular for public sector employees. However, this area is far less studied than work-related outcomes (Culbertson, Huffman, and Alden-Anderson 2009).

\subsection{Background on meaningfulness}

In this article, the concept of meaningfulness at work is considered as a potential mediator between LMX and outcomes. Here, it is useful to first describe the background of meaningfulness. We will discuss the background of the meaningfulness concept, linking it to 
various literature streams, such as work and organizational sociology (particularly alienation studies) and work and organizational psychology (empowerment, job characteristics model, engagement).

The concept of meaningfulness builds on the alienation tradition that comes from the sociology of work and organization field. Alienation broadly refers to a sense of social estrangement, an absence of social support or meaningful social connection. The intellectual roots of the alienation concept are found in the work of Karl Marx (1961 [1844]) who focused on objective work alienation: workers become alienated when they do not own the means of production or the resulting product. Many sociologists writing on alienation draw on Marx although, in contrast to Marx, they focus on subjective work alienation: alienation as perceived by the worker (DeHart-Davis and Pandey 2005).

Social scientists have used the (subjective) alienation concept in various studies and a number of meanings have been attributed to the term. In an attempt to provide clarity, Seeman (1959) broke these meanings down into five alienation dimensions: powerlessness, meaninglessness, normlessness, social isolation, and self-estrangement. Of these dimensions, powerlessness and meaningless are considered to be particularly important (DeHart-Davis and Pandey 2005; Tummers 2011). This article focuses on the role of meaningfulness/meaninglessness. In a work setting, meaninglessness can occur "when workers are not able to understand the complex system of goals in the organization and its relationship to their own work" (Kanungo 1982:26).

The meaninglessness/meaningfulness of work concept can also be found in the work and organizational psychology field. Here, it is firstly related to literature on psychological empowerment literature. Spreitzer (1995:1443) notes that meaning of work is one of the four components of psychological empowerment. It is described as the fit between the requirements of a work role and one's own beliefs, values, and behaviors. In a recent review 
by Maynard et al. (2012) it was concluded that, of the four components of psychological empowerment, meaning of work had the strongest relationship with job satisfaction (see also Liden, Wayne, and Sparrowe 2000). Overall, it was found that certain components of psychological empowerment are potential mediators between various work antecedents (such as leadership) and work outcomes (such as job satisfaction and organizational commitment). This article follows a similar line of reasoning in analyzing work meaningfulness as a potential mediator between LMX and outcomes.

Next, the concept of meaningfulness is also discussed in the job characteristics model of Hackman and Oldham (1980). The meaningfulness experienced in work is seen as a key psychological state that mediates the relationships between core job characteristics and outcomes. In a meta-analysis, Humphrey et al. (2007) found that experienced meaningfulness was the primary mediator between job characteristics and outcomes. As such, meaningfulness seems to be an important mediator when relating job characteristics to outcomes (see also Arnold et al. 2007; Clausen and Borg 2011).

Work meaningfulness is also related to the concept of work engagement although these concepts also notably differ. Schaufeli et al. (2002:74) define engagement as "a positive, fulfilling work-related state of mind that is characterized by vigor, dedication, and absorption". They state that engaged employees have a sense of energetic and effective connection with their work activities, and see themselves as able to deal well with the demands of their jobs. In this article, work meaningfulness is defined as 'an employee's perception that he/she is able to understand the complex system of goals in the organization and its relationship to his/her own work' and this has both similarities as well as differences with the work engagement concept. On the one hand, both the meaningfulness and engagement concepts refer to work-related attitudes and both are positive psychological states. However, while engagement refers to job demands in relation to an employee's own 
abilities, meaningfulness refers to the goals of the organization in relation to an employee's own work. One could argue that the concepts are related in the sense that meaningful work can result in greater employee engagement (Olivier and Rothmann 2007).

A few remarks can be made regarding analyzing the role of meaningfulness specifically in public organizations. However, it must be stated that making a simple distinction between public organizations on the one hand, and private organizations on the other, seems overly simplistic (Rainey and Bozeman 2000). Besides their public, semi-public, or private legal status, many characteristics influence organizations and their working environments such as size, location, environment, and function. Notwithstanding this remark, it can be argued that public organizations have considerable goal complexity and goal ambiguity (Rainey and Bozeman 2000; Jung 2011). In an organization with substantial goal complexity and ambiguity, it could be difficult for employees to understand the contribution of their specific work to the organization or to society or, in other words, to feel that their work is meaningful. On the other hand, many people chose to work in the public sector given that they aim to do meaningful work and contribute to society (Perry and Hondeghem 2008). Hence, studying work meaningfulness - and ways to improve it - could be quite important in public sector settings.

\subsection{Leadership, meaningfulness, and outcomes}

In this section, the relationships between LMX, meaningfulness, and three relevant outcomes are analyzed. Figure 1 displays the conceptual model outlining the relationships between the variables in this study. 


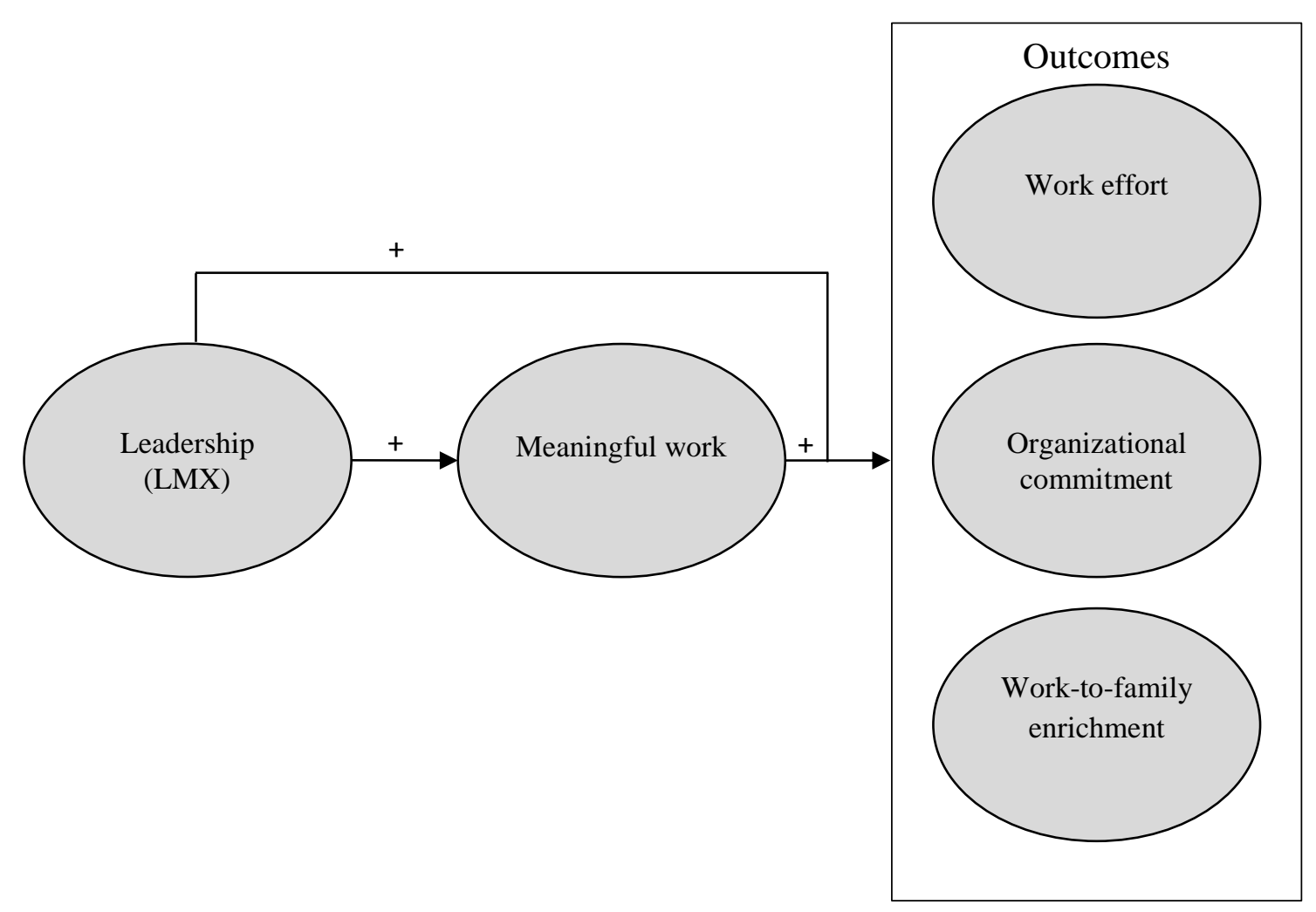

Figure 1 Hypothesized relationships between leadership, meaningful work, and outcome dimensions

We first analyze how LMX influences meaningfulness at work. One would intuitively expect the degree of LMX to positively influence experienced meaningfulness. When the relationship between leaders and employees is of high quality, employees are given greater decisional latitude and are provided with more opportunities to participate. This makes it easier for them to make meaningful contributions to the organization and to society, and increases their understanding of their role within it. Hence, it can enhance their experienced meaningfulness at work (see also Aryee and Chen 2006).

On this basis, one can consider how the outcomes are influenced. First, we look at two important effects on the work level: affective organizational commitment and work effort. These effects were selected given their importance for organizational performance (McAllister 1995; Meyer et al. 2002). 
Affective organizational commitment is defined as an "employee's emotional attachment to, identification with, and involvement in the organization" (Allen and Meyer 1997:11). Employees who experience affective commitment stay with an organization because they genuinely want to, because they can identify with that organization. Following Gerstner and Day (1997), one would expect the level of LMX to be positively related to the degree of organizational commitment. Further, if employees feel that their work is meaningful, this will increase their organizational commitment - and they will stay with their organization because they want to (Pierce and Dunham 1987).

Work effort refers to the extent to which employees exert effort that goes beyond their formal job requirements (Gould-Williams 2004). It seems that, for organizations, it is paramount that employees 'go the extra mile'. One could expect the level of LMX to be positively related to work effort. Here, Kacmar et al. (2007) showed that LMX significantly influenced the level of self-assessed work effort. Moreover, we also expect meaningfulness to positively influence the effort that workers put into their work. Cummings and Manring (1977) found that meaningfulness was positively related to work effort and performance. Further, Arnold et al. (2007:195) note that "higher purpose [or less meaninglessness] was associated with increased job satisfaction, perceptions of unit cohesion, and work effort”.

In addition to organizational commitment and work effort, an outcome outside of work is considered: work-to-family enrichment. Work-family researchers have examined both negative and positive relationships between work and family life. Initially, the main focus was on the work-family conflict although, more recently, the positive relationships between work and family have been emphasized through work-to-family enrichment (Greenhaus and Powell 2006). Work-to-family enrichment occurs when resources from the former improve performance in or positively affect the latter. This study focuses on the affective dimension of work-to-family enrichment, that is "when involvement in work results in a positive emotional 
state or attitude which helps the individual to be a better family member" (Carlson et al. 2006:140). For instance, work-to-family enrichment occurs when you feel valued at work (such as because you can help students with their theses) and, because of this, you are in a good mood at home. We would expect high LMX to increase work-to-family enrichment (see also Bernas and Major 2000). Further, work meaningfulness may create a positive emotional state and consequently increase the likelihood that work-to-family enrichment occurs (Hackman and Oldham 1980).

In the discussion above, a link was established between both LMX and meaningfulness and three outcomes. Further, it was hypothesized that LMX influences meaningfulness. Given its attitudinal foundations, meaningfulness is seen as closer than LMX to the outcome dimensions, and it should therefore serve as a mechanism through which LMX influences the outcomes dimensions (see also Aryee and Chen 2006). However, we do not expect the relationship between LMX and the outcomes to be fully mediated by the level of meaningfulness. Rather we expect the level of LMX experienced by employees to also have a direct effect on the outcomes. For example, if employees experience high levels of LMX they will work harder not only because of the increased meaningfulness, but also because they want to 'return the favor' (Graen and Uhl-Bien 1995). Thus, overall, we expect the relationship between LMX and the studied outcomes to have both direct and indirect (through meaningfulness) components. Based on the above, the following hypotheses are formulated:

H1a: LMX has a positive direct effect on organizational commitment.

H1b: LMX has a positive indirect, through the level of meaningfulness, effect on organizational commitment.

H2a: LMX has a positive direct effect on work effort.

H2b: LMX has a positive indirect, through the level of meaningfulness, effect on work effort. 
H3a: LMX has a positive direct effect on work-to-family enrichment.

H3b: LMX has a positive indirect, through the level of meaningfulness, effect on work-tofamily enrichment.

\section{Method}

\subsection{Testing the proposed model using survey data from three sectors}

This section describes the survey procedures used to test the hypotheses. As suggested by Perry (2012), we have analyzed our procedures using the 'total survey error framework' of

Lee et al. (2012). The total survey error framework assesses the quality of the techniques used in conducting a survey. In using this framework, shown in table 1, researchers aim to increase the quality of their studies. In order to improve the reliability and validity of the findings, we have taken various measures in order to keep the possible errors identified by Lee et al. (2012) to a minimum. 
Table 1 Description of Total Error Framework used to assess Public Administration articles (see Lee et al., 2012), and the test for each potential error in the data used

\begin{tabular}{|c|c|c|c|}
\hline $\begin{array}{l}\text { Type of } \\
\text { error }\end{array}$ & Description of error & $\begin{array}{l}\text { Possible ways to } \\
\text { avoid error }\end{array}$ & $\begin{array}{l}\text { Testing for potential errors in the data } \\
\text { used }\end{array}$ \\
\hline $\begin{array}{l}\text { Coverage } \\
\text { errors }\end{array}$ & $\begin{array}{l}\text { A form of non-sampling error } \\
\text { occurring when the target } \\
\text { population and the sample } \\
\text { frame(s) are mismatched in } \\
\text { terms of coverage. }\end{array}$ & $\begin{array}{l}\text { Show construction of } \\
\text { sampling frame and } \\
\text { how it overlaps with } \\
\text { the intended } \\
\text { population }\end{array}$ & $\begin{array}{l}\text { Target populations are specified } \\
\text { (healthcare, especially midwives, local } \\
\text { government employees, employees in } \\
\text { education). Sampling frames have been } \\
\text { specified. Given the size of target } \\
\text { populations, some coverage error was } \\
\text { unavoidable (survey of midwives, two } \\
\text { municipalities, two education institutions). } \\
\text { However, for each group, we have } \\
\text { specified the similarity of the respondents, } \\
\text { in terms of gender and age, with the } \\
\text { overall target population, with satisfying } \\
\text { results. }\end{array}$ \\
\hline $\begin{array}{l}\text { Sampling } \\
\text { errors }\end{array}$ & $\begin{array}{l}\text { "Sampling error arises when } \\
\text { the entire target population, } \\
\text { or universe, is not selected } \\
\text { and decreases as the } \\
\text { sample size increases." }\end{array}$ & $\begin{array}{ll} & \text { High sampling } \\
\text { size and report } \\
\text { sample size } \\
\text { - Use of } \\
\text { probability } \\
\text { sampling }\end{array}$ & $\begin{array}{l}\text { For the surveys in local government and } \\
\text { for education, parts of the organizations } \\
\text { have been approached (given the size of } \\
\text { the organizations). All sample sizes have } \\
\text { been reported, and are quite high ( } 1,278 \\
\text { healthcare, } 473 \text { local government, } 881 \\
\text { education). }\end{array}$ \\
\hline $\begin{array}{l}\text { Non- } \\
\text { response } \\
\text { error }\end{array}$ & $\begin{array}{l}\text { Non-response errors occur } \\
\text { when there are systematic } \\
\text { differences in responses } \\
\text { between respondents and } \\
\text { the total sample }\end{array}$ & $\begin{array}{ll}- & \text { Enhancing } \\
\text { response rates } \\
\text { \& report } \\
\text { response rate } \\
\text { Conduct non- } \\
\text { response } \\
\text { survey }\end{array}$ & $\begin{array}{l}\text { Follow up mail sent to increase } \\
\text { response rate } \\
\text { Response rates shown }(61 \% \\
\text { healthcare, } 48 \% \text { local government, } \\
29 \% \text { education) } \\
\text { Non-response surveys were } \\
\text { conducted and these did not suggest } \\
\text { a bias in our results (common } \\
\text { reasons given were, for instance, } \\
\text { lack of time) }\end{array}$ \\
\hline $\begin{array}{l}\text { Measurement } \\
\text { error }\end{array}$ & $\begin{array}{l}\text { Many sources of } \\
\text { measurement error exist, } \\
\text { such as difficulty in } \\
\text { interpreting questions and } \\
\text { social desirability }\end{array}$ & $\begin{array}{l}\text { High quality of } \\
\text { questionnaire (use } \\
\text { validated scales or } \\
\text { discuss } \\
\text { questionnaire with } \\
\text { target population) }\end{array}$ & $\begin{array}{l}\text { - All used scales have been validated } \\
\text { in earlier research } \\
\text { Social desirability is unlikely to be a } \\
\text { major issue given the nature of the } \\
\text { questions (see also Lee et al., } \\
2011: 92 \text { ) }\end{array}$ \\
\hline $\begin{array}{l}\text { Processing } \\
\text { error }\end{array}$ & $\begin{array}{l}\text { Processing errors occur } \\
\text { after data collection, such as } \\
\text { in data coding, editing, } \\
\text { weighting, and estimation } \\
\text { procedures }\end{array}$ & 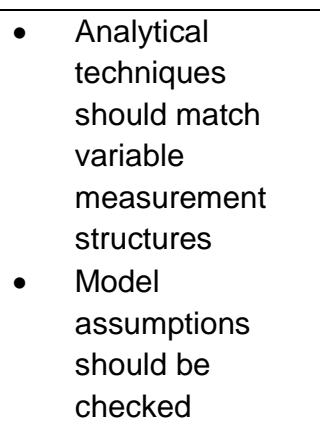 & 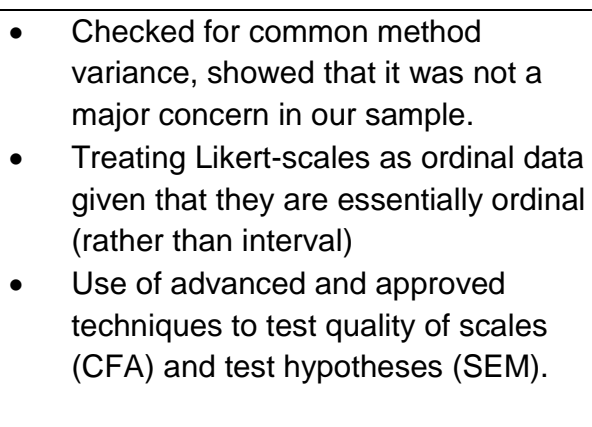 \\
\hline
\end{tabular}


Survey data from three sectors were collected: education, healthcare (midwives), and local government (municipalities). These sectors were chosen as they potentially differ in their degree of meaningfulness: whereas work in education and healthcare is often perceived as meaningful, it is sometimes harder to see working for local government as contributing to society. This difference could influence the mediating mechanisms.

We initially established contact with organizations and asked whether they would agree to participate in the research project. We then contacted respondents via email, including a link to the questionnaire, which also described the research project and its objectives, and stressed anonymity. Two follow-up mails were also sent to increase the response rate.

In the healthcare sector, our sample consisted of 1,278 midwives. We chose to focus particularly on midwives given that they were expected to perceive their work as very meaningful. ${ }^{1}$ We received 790 completed questionnaires, a response of $61 \%$. Of the valid responses, $97.2 \%$ were from women and their average age was 40 . This is consistent with national figures for midwives, which is a traditionally female occupation (97\% female), with a mean age of 37 (Hingstman and Kenens 2011). For the local government group, we surveyed employees from the two largest Dutch municipalities (Amsterdam and Rotterdam). We invited 473 employees to participate and received 229 completed questionnaires. Again, the responding sample (54.1\% female and average age 43$)$ was somewhat similar to the Dutch municipal averages: 46\% female (Ministry of the Interior 2010), average age 43 (CBS 2010). In the education sector, we invited 881 employees from a school for intermediate vocational education and 200 university employees. The overall response rate was 29\% (313 employees).

\footnotetext{
${ }^{1}$ Our results are therefore applicable only to the population of midwives, not to healthcare workers in general (matching target population and sampling frame, see Lee et al., 2012).
} 
Here, the average age of the respondents was 47 years, and $63.8 \%$ were female. This is again somewhat similar to the Dutch education averages: 62\% female and age 43 (CBS 2010).

For all three sectors, we performed a non-response analysis. Results showed that employees did not participate due to: a lack of time, technical difficulties completing the online instrument, and the fact that they already had to fill out a lot of questionnaires. This analysis does not suggest any severe bias in our sample.

\subsection{Measures}

The variables were all measured using five-point Likert scales, where a 1 indicated very weak support for the item statement, and a 5 very strong support.

Leader-member exchange - The LMX scale of Liden et al. (1993) made up of seven items was used. A sample item was "I feel that my immediate supervisor understands my problems and needs". Cronbach's alpha for the scale was .919.

Meaningfulness - The concept of meaningfulness is based on the alienation tradition, which considers its opposite: meaninglessness. We used five items ${ }^{2}$ from Mottaz' (1981) often-applied scale. We retained all the items but reversed the answers (recoded, R) in the statistical analyzes. A sample item was "I often wonder what the importance of my job really is" (R). Cronbach's alpha was .815.

Organizational commitment - Allen and Meyer (1990) developed a number of items to measure affective organizational commitment. We used the five best-fitting items from this scale. A sample item was "I feel a strong sense of belonging to my organization". Cronbach's alpha was .893.

\footnotetext{
${ }^{2}$ The seven items in the original scale were measured in the questionnaire. However, given that CFA test is often more stringent than the Cronbach's alpha reliability measure (Kline 2010), two items were taken out in order to improve the fit. This method was also applied to the scales for organizational commitment and work effort to improve fit.
} 
Work effort - We used the eight-item work-effort scale developed by Gould-Williams (2004) to measure employee discretionary effort. We used the five best-fitting items. A sample item was "I volunteer for things that are not part of the job". Cronbach's alpha was .683 .

Work-to-family enrichment - We included the three-item affect dimension of work-tofamily enrichment based on Carlson et al. (2006:140). A sample item is "My involvement in my work puts me in a good mood and this helps me be a better family member" (Carlson et al. 2006). Cronbach's alpha was .926.

Control variables - We also included commonly used control variables: gender, age, supervisory tasks (yes/no), number of working hours, children living at home (yes/no) (possibly relevant given the focus on work-family interference), and level of education (1=primary school, 2=secondary school, 3=intermediate vocational education, 4=higher vocational education, 5=academic education, 6=postgraduate (e.g. specialization or $\mathrm{PhD}$ )).

\subsection{Measurement Quality and Data Analysis}

Confirmatory Factor Analysis (CFA) was used to test the hypotheses followed by Structural Equation Modeling (SEM). The CFA and SEM techniques are often used in psychological research but are relatively new to most public administration scholars (but see for instance Wright, Moynihan, and Pandey 2012; Tummers and Bekkers forthcoming 2014). We therefore discuss a number of the analyses' characteristics in some detail.

Confirmatory factor analysis is a technique used to test the factor structure of latent constructs based on theory and prior research experience. This is appropriate here given that previous analyses have already explored some of the variables such as LMX. CFA has several advantages over exploratory factor analysis, such as more stringent psychometric criteria for accepting models, and this improves both validity and reliability (Brown 2006). 
A CFA results in a measurement model being specified. This model specifies the number of factors and shows how the indicators (i.e. items) relate to the various factors. For instance, it shows how the items measuring work-to-family enrichment relate to the latent construct of work-to-family enrichment. The results of the CFA confirm the factor structure described earlier. The standardized coefficients all had adequate values between 0.514 and $0.984(p<.001)$. This shows evidence of convergent validity: that is, items that tap the same latent construct are related to each other (Kline 2010).

The measurement model is a precursor for the SEM analyses where a structural model is constructed showing how the various latent factors relate to each other (see Results). In an SEM analysis, a total model can be tested where variables can be both dependent and independent, one of the advantages over regression analyzes. Given that, in our model, the work meaningfulness variable is both dependent, being hypothetically influenced by LMX, and independent, hypothetically influencing outcomes, this was appropriate.

The data analysis was carried out using Mplus (Muthén and Muthén 1998-2010). Data are often non-normally distributed when employing surveys, but this reality is frequently ignored by researchers. Here, the non-normal distribution of the data was taken into account by using the Weighted Least Squares with a robust estimator approach available within Mplus.

The data for all items were collected from individual respondents and are thus potentially subject to common method bias (CMB) (Podsakoff et al. 2003). Although a recent study showed that "in contrast to conventional wisdom, common method effects do not appear to be so large as to pose a serious threat to organizational research" (Lance et al. 2010:450), we have addressed this potential problem in various ways. In the survey design, we spread the items relating to different variables across various sections of the questionnaire. Further, we conducted two sets of CFAs to check for CMB in the data, comparing the 
hypothesized structure with a one-factor model. The analyses provide evidence against there being a bias stemming from common method variance. Hence, CMB does not appear to be a serious concern.

\section{Results}

\subsection{Descriptive statistics}

Descriptive statistics and correlations of the variables are presented in table 2. Respondents were fairly positive about the support they receive from their leaders and reported a high level of work meaningfulness. Table 3 shows the descriptive statistics for respondents employed in the various sectors. There are significant differences between the groups. Healthcare employees have the highest scores for all the variables. Employees working in education are generally slightly more positive than municipality employees. 
Table 1 Descriptive statistics and correlations for the variables in the study

\begin{tabular}{|c|c|c|c|c|c|c|c|c|c|c|c|c|c|c|}
\hline \multicolumn{2}{|c|}{ Variable } & Mean & SD & 1 & 2 & 3 & 4 & 5 & 6 & 7 & 8 & 9 & 10 & 11 \\
\hline 1. & $\begin{array}{l}\text { Gender }(0=\text { male; } \\
1=\text { female })\end{array}$ & $82.4 \%$ & n.a. & 1 & & & & & & & & & & \\
\hline 2. & Age & 42.23 & 11.66 & $-.225^{\star \star *}$ & 1 & & & & & & & & & \\
\hline 3. & Educational level & 4.00 & 0.75 & $.221^{\star \star \star}$ & $-.111^{* * *}$ & 1 & & & & & & & & \\
\hline 4. & $\begin{array}{l}\text { Supervisory tasks } \\
(0=\text { no; } 1=\text { yes })\end{array}$ & $17.4 \%$ & n.a. & -.027 & .052 & $.220^{\star \star \star *}$ & 1 & & & & & & & \\
\hline 5. & No. of working hours & 35.84 & 13.28 & $-.131^{* * *}$ & $-.158^{* * *}$ & $.074^{*}$ & $.219^{* * *}$ & 1 & & & & & & \\
\hline 6. & $\begin{array}{l}\text { Children at home } \\
\text { (0=no; } 1=\text { yes })\end{array}$ & $56.2 \%$ & n.a. & .052 & -.044 & $.072^{*}$ & .060 & $-.109^{\star *}$ & 1 & & & & & \\
\hline 7. & LMX & 3.42 & 0.78 & .061 & .001 & .000 & $.096^{*}$ & -.089 & .046 & 1 & & & & \\
\hline 8. & Meaningfulness & 4.17 & 0.51 & $.086^{\star *}$ & $-.073^{*}$ & $.100^{* *}$ & $.163^{\star \star \star}$ & $.119^{\star *}$ & $.099^{* *}$ & $.332^{* \star *}$ & 1 & & & \\
\hline 9. & $\begin{array}{l}\text { Organizational } \\
\text { commitment }\end{array}$ & 3.68 & 0.82 & $.219^{\star \star \star}$ & $-.137^{\star *}$ & $.146^{\star \star \star}$ & $.167^{\star * *}$ & $.227^{\star * *}$ & $.080^{*}$ & $.439^{\star * *}$ & $.537^{\star \star \star}$ & 1 & & \\
\hline 10. & Work effort & 4.01 & 0.53 & $.159^{\star \star \star}$ & -.003 & $.082^{*}$ & $.221^{* * *}$ & $.163^{\star * *}$ & .061 & $.235^{\star * *}$ & $.448^{\star \star \star}$ & $.442^{\star * *}$ & 1 & \\
\hline 11. & $\begin{array}{l}\text { Work-to-family } \\
\text { enrichment }\end{array}$ & 3.55 & 0.79 & $.109^{* *}$ & -.034 & .057 & .029 & $-.091^{* *}$ & $.085^{\star}$ & $.292^{* \star *}$ & $.274^{\star \star *}$ & $.302^{\star \star \star}$ & $.282^{\star \star \star}$ & 1 \\
\hline
\end{tabular}


Table 3 Descriptive statistics for the sectors in our study

\begin{tabular}{|c|c|c|c|c|c|c|c|c|c|c|}
\hline & \multicolumn{2}{|c|}{ LMX } & \multicolumn{2}{|c|}{ Meaningfulness } & \multicolumn{2}{|c|}{ Commitment } & \multicolumn{2}{|c|}{ Work effort } & \multicolumn{2}{|c|}{ Work-to-Family enrichmen } \\
\hline & mean & SD & mean & SD & mean & SD & mean & SD & Mean & SD \\
\hline Healthcare & 3.50 & 0.72 & 4.26 & 0.43 & 3.96 & 0.72 & 4.08 & 0.51 & 3.61 & 0.72 \\
\hline Municipalities & 3.35 & 0.86 & 3.95 & 0.61 & 3.12 & 0.74 & 3.87 & 0.57 & 3.36 & 0.96 \\
\hline Education & 3.35 & 0.82 & 4.04 & 0.60 & 3.25 & 0.76 & 3.91 & 0.56 & 3.52 & 0.88 \\
\hline Total & 3.42 & 0.78 & 4.17 & 0.51 & 3.68 & 0.82 & 4.01 & 0.53 & 3.55 & 0.79 \\
\hline ANOVA $(F)$ & $3.593^{*}$ & & $35.150^{* * *}$ & & $155^{* * *}$ & & $16.680^{* * *}$ & & $7.997^{* *}$ & \\
\hline
\end{tabular}




\subsection{SEM results}

The results presented in table 4 show that - for the overall model - a good model fit was achieved $(\mathrm{CFI}=.987$, TLI=.985, RMSEA=.045). The results indicate that LMX has a direct effect on all the outcome variables. This thus offers support for hypotheses H1a, H2a, and H3a. LMX is also significantly related to meaningfulness. In turn, meaningfulness has a significant relationship with all the outcome variables. The results indicate that the relationships between meaningfulness and the outcome variables are stronger than those between LMX and the outcome variables. We also tested for indirect effects: of LMX, through meaningfulness, on commitment, on work effort, and on work-to-family enrichment. All these indirect paths are significant, supporting hypotheses $\mathrm{H} 2 \mathrm{a}, \mathrm{H} 2 \mathrm{~b}$, and $\mathrm{H} 2 \mathrm{c}$.

Overall, the levels of explained variance are quite high. First, regarding commitment, the model explained $40.4 \%$ of the variance. This is attributed to the direct and mediated effects of LMX and to the significant control variables (gender and number of working hours). Women and those who work long hours report higher levels of commitment. The level of work-effort variance explained is $23.8 \%$. Gender, supervisory tasks, number of working hours, and the direct and mediated effect of LMX contributed to explaining this variance. ${ }^{3}$ Women, supervisors, and those who work the most hours report higher levels of work effort. The model explained $11.6 \%$ of the variance in work-to-family enrichment. The direct and mediated effects of LMX were significant as well as the gender and number of working hours control variables. Women report higher levels of work-to-family enrichment than men, as did those working fewer hours.

\footnotetext{
${ }^{3}$ The scores for the control variables are not shown in table 4 due to space restrictions. Where the control variables were significant, this is noted in the body text.
} 
Additional SEM analyses were conducted to test the model in the various sectors. Fit indices indicate a strong fit in all three sectors: healthcare (CFI=.983; TLI=.980; RMSEA=.045), municipalities $(\mathrm{CFI}=.979 ; \quad \mathrm{TLI}=.976 ; \quad \mathrm{RMSEA}=.047)$, and education (CFI=.983; TLI=0.980; RMSEA=0.043), showing the robustness of the model. The results indicate that, in healthcare, all the paths outlined above are significant. In local government, meaningfulness is only a significant mediator in the case of work effort. The indirect paths are not significant for commitment and work-to-family enrichment. In the education sector, the direct paths from LMX to work effort and to work-to-family enrichment are not significant, meaning that the relationships between LMX and these two outcomes variables are fully mediated by meaningfulness. 
Table 4 Results of the SEM analyses

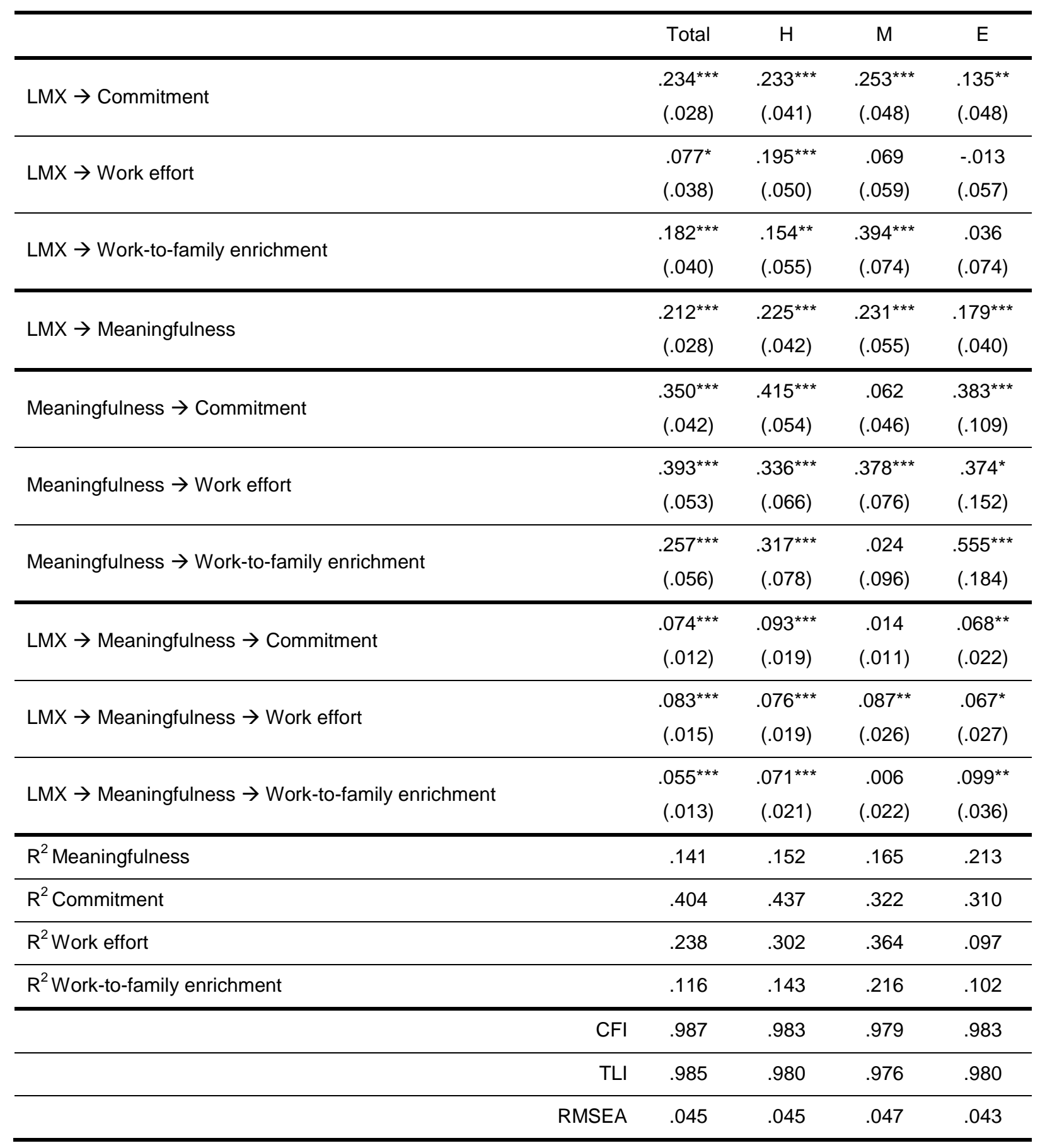

Note: ${ }^{*} p<.05,{ }^{* \star} p<.01,{ }^{* \star *} p<.001$. Unstandardized coefficients are presented (standard errors in parentheses). The control variables are not reported due to space limitations but can be provided by the authors. $\mathrm{H}=$ Healthcare; $\mathrm{M}=$ Municipalities; $\mathrm{E}=$ Education 


\section{Conclusions and discussion}

This study contributes to understanding leadership in public sector organizations in two ways. First, as encouraged by Van Wart (2013), by developing an explicit theoretical model and then testing this with data from various public sector settings. Secondly, by focusing on the dynamics/mechanisms of leadership: analyzing the mechanisms at play to explain how a better relationship between employees and their leaders boosts outcomes. More specifically, the role of work meaningfulness was analyzed as a potential mediator between LMX and outcomes, both inside and beyond the work context.

The results indicate that the meaningfulness of work is an important mediator between leadership and outcomes, in line with theoretical expectations. When employees and managers have a good relationship (i.e. high LMX), this positively affects employees' perceptions of making a difference in their work and in seeing the relationship of their work to the larger organization. This is possibly because, in such situations, leaders provide employees with greater insight into how the organization works and give them more responsibility. In return, this results in higher organizational commitment, greater work effort, and enriches work-to-family crossover. This emphasizes the importance of meaningful work. This is significant as many organizational behavior and leadership scholars play down the importance of meaningfulness (but see May, Gilson, and Harter 2004). Organizational behavior scholars tend to focus on autonomy or job control (see for instance Deci and Ryan 2004). While the role of participative management is well researched in leadership theory (for instance Kim 2002), there is much less research on meaningful work. The current research suggests that the role of meaningfulness is significant and an important study topic regarding leadership issues in the public management discipline. An interesting avenue here could be to combine the leadership literature concerning meaningfulness with insights from Public Service Motivation (PSM) (Vandenabeele 2008). 
The findings show that the mechanisms that connect LMX and outcomes vary between sectors. In healthcare, LMX has both a direct effect on outcomes and an indirect one through meaningful work. In education, meaningfulness is an even more important mechanism: it fully mediates the relationships between LMX and both work effort and workto-family enrichment. In other words, if teachers have a good relationship with their supervisor, this will increase the meaningfulness of their work, and this will have positive effects for the organization and for the employee. When it comes to local government, LMX has a direct relationship only with commitment and work-to-family enrichment, and meaningfulness does not play a significant role as a mediator. It would seem, particularly in education and also in healthcare, that the level of meaningfulness is an important predictor of outcomes whereas, in local government, employees seem to be committed and experience work-to-family enrichment regardless of the meaningfulness they perceive in their jobs. It could be that employees in healthcare and education chose to work in these sectors because they want to perform meaningful work whereas, in local government, employees have other motives, such as job security and regular pay increases, reducing the role of meaningful work (Jurkiewicz and Massey 1996). This argument would fit the descriptive statistics that show that perceived meaningfulness is lower in the local government sector than in the other two investigated. A further possibility is that it could also be caused by the nature of supervisoryemployee relationships differing among sectors; managing a healthcare professional is obviously quite a different task to managing a local government employee (see also Mintzberg 1998).

We end this article by discussing some of its limitations. First, some of the variables in the dataset demonstrated limited variability. This is particularly the case for the variable meaningfulness. Although all possible scores are represented in the dataset, attenuated ranges could result in either over or under estimates of effect sizes. It could be that the high mean 
score for meaningfulness is a consequence of conducting the study in the public sector. That is, employees typically opt to work in the public sector because they want to contribute to society, i.e. to do meaningful work. It would be interesting to compare public and private sector employees in future studies. Another methodological limitation is the use of crosssectional data. As such, assumptions based on theoretical arguments are made about the likely direction of causality, moving from leadership, through meaningfulness, to outcomes. Future studies could employ longitudinal or experimental designs that could test the causality of these relationships.

Concluding, our empirical results emphasize the importance of leadership in the public sector. In line with Wright and Pandey (2010:86), we note that "management matters" (Rainey and Steinbauer 1999; Pandey, Coursey, and Moynihan 2007; see also Hennessey Jr 1998; Knies 2012). Our research findings highlight the importance of studying and improving leadership in the public sector, and especially the need to relate leadership with meaningful work. Further, by testing explicit theoretical models in various parts of the public sector, this study has highlighted important differences between various parts of the public sector. 


\section{References}

Allen, N. J. and J. P. Meyer. 1997. Commitment in the Workplace: Theory, Research, and Application. London: Sage.

- 1990. "The Measurement and Antecedents of Affective, Continuance and Normative Commitment to the Organization." Journal of Occupational Psychology 63 (1): 1-18.

Arnold, K. A., N. Turner, J. Barling, E. K. Kelloway, and M. C. McKee. 2007.

"Transformational Leadership and Psychological Well-being: The Mediating Role of Meaningful Work." Journal of Occupational Health Psychology 12 (3): 193-203.

Aryee, S. and Z. X. Chen. 2006. "Leader-Member Exchange in a Chinese Context: Antecedents, the Mediating Role of Psychological Empowerment and Outcomes." Journal of Business Research 59 (7): 793-801.

Bernas, K. H. and D. A. Major. 2000. "Contributors to Stress Resistance: Testing a Model of Women's Work-Family Conflict." Psychology of Women Quarterly 24 (2): 170-178.

Blau, P. M. 1964. Exchange and Power in Social Life. New York: Wiley.

Brown, T. A. 2006. Confirmatory Factor Analysis for Applied Research. London: The Guilford Press.

Brunetto, Yvonne, Rod Farr-Wharton, Sheryl Ramsay, and Kate Shacklock. 2010. "Supervisor Relationships and Perceptions of Work—family Conflict." Asia Pacific Journal of Human Resources 48 (2): 212-232. 
Carlson, D. S., K. M. Kacmar, J. H. Wayne, and J. G. Grzywacz. 2006. "Measuring the Positive Side of the Work-Family Interface: Development and Validation of a WorkFamily Enrichment Scale." Journal of Vocational Behavior 68 (1): 131-164.

CBS. "Statline.", accessed 15 December, 2012, http://statline.cbs.nl/.

Clausen, T. and V. Borg. 2011. "Job Demands, Job Resources and Meaning at Work." Journal of Managerial Psychology 26 (8): 665-681.

Culbertson, S. S., A. H. Huffman, and R. Alden-Anderson. 2009. "Leader-Member Exchange and Work-Family Interactions: The Mediating Role of Self-Reported Challenge-and Hindrance-Related Stress." The Journal of Psychology 144 (1): 15-36.

Cummings, T. G. and S. L. Manring. 1977. "The Relationship between Worker Alienation and Work-Related Behavior." Journal of Vocational Behavior 10 (2): 167-179.

Deci, E. L. and R. M. Ryan. 2004. Handbook of Self-Determination Research. Rochester: Univ of Rochester Pr.

DeHart-Davis, L. and S. K. Pandey. 2005. "Red Tape and Public Employees: Does Perceived Rule Dysfunction Alienate Managers?" Journal of Public Administration Research and Theory 15 (1): 133-148.

Dulebohn, James H., William H. Bommer, Robert C. Liden, Robyn L. Brouer, and Gerald R. Ferris. 2012. "A Meta-Analysis of Antecedents and Consequences of Leader-Member Exchange Integrating the Past with an Eye Toward the Future." Journal of Management 38 (6): 1715-1759. 
Fernandez, S. 2005. "Developing and Testing an Integrative Framework of Public Sector Leadership: Evidence from the Public Education Arena." Journal of Public Administration Research and Theory 15 (2): 197.

Gerstner, C. R. and D. V. Day. 1997. "Meta-Analytic Review of Leader-member Exchange Theory: Correlates and Construct Issues." Journal of Applied Psychology 82 (6): 827844.

Gould-Williams, J. 2004. "The Effects of 'high Commitment' HRM Practices on Employee Attitude: The Views of Public Sector Workers." Public Administration 82 (1): 63-81.

Graen, G. B. and M. Uhl-Bien. 1995. "Relationship-Based Approach to Leadership: Development of Leader-Member Exchange (LMX) Theory of Leadership Over 25 Years: Applying a Multi-Level Multi-Domain Perspective." The Leadership Quarterly 6 (2): 219-247.

Greenhaus, J. H. and G. N. Powell. 2006. "When Work and Family are Allies: A Theory of Work-Family Enrichment." The Academy of Management Review ARCHIVE 31 (1): 7292.

Hackman, J. R. and G. R. Oldham. 1980. Work Redesign. Reading, MA: Addison Wesley.

Hansen, J. R. and A. R. Villadsen. 2010. "Comparing Public and Private Managers' Leadership Styles: Understanding the Role of Job Context." International Public Management Journal 13 (3): 247-274.

Harris, Kenneth J., Anthony R. Wheeler, and K. Michele Kacmar. 2009. "Leader-member Exchange and Empowerment: Direct and Interactive Effects on Job Satisfaction, Turnover Intentions, and Performance." The Leadership Quarterly 20 (3): 371-382. 
Hennessey Jr, J. T. 1998. "" Reinventing" Government: Does Leadership make the Difference?" Public Administration Review (6): 522-532.

Hingstman, L. and R. J. Kenens. 2011. Cijfers Uit De Registratie Van Verloskundigen: Peiling 2011. Utrecht: Nivel.

Howell, J. M. and K. E. Hall-Merenda. 1999. "The Ties that Bind: The Impact of LeaderMember Exchange, Transformational and Transactional Leadership, and Distance on Predicting Follower Performance." Journal of Applied Psychology 84 (5): 680-694.

Humphrey, S. E., J. D. Nahrgang, and F. P. Morgeson. 2007. "Integrating Motivational, Social, and Contextual Work Design Features: A Meta-Analytic Summary and Theoretical Extension of the Work Design Literature." Journal of Applied Psychology 92 (5): 1332-1356.

Jung, Chan Su. 2011. "Organizational Goal Ambiguity and Performance: Conceptualization, Measurement, and Relationships." International Public Management Journal 14 (2): 193-217.

Jurkiewicz, C. L. and T. K. Massey. 1996. "What Municipal Employees Want from their Jobs Versus what they are Getting: A Longitudinal Comparison." Public Productivity \& Management Review 20 (2): 129-138.

Kacmar, K. M., S. Zivnuska, and C. D. White. 2007. "Control and Exchange: The Impact of Work Environment on the Work Effort of Low Relationship Quality Employees." The Leadership Quarterly 18 (1): 69-84.

Kanungo, R. N. 1982. Work Alienation: An Integrative Approach. New York: Praeger Publishers. 
Kim, S. 2002. "Participative Management and Job Satisfaction: Lessons for Management Leadership." Public Administration Review 62 (2): 231-241.

Kline, R. B. 2010. Principles and Practice of Structural Equation Modeling. London: The Guilford Press.

Knies, E. 2012. Meer Waarde Voor En Door Medewerkers: Een Longitudinale Studie Naar De Antecedenten En Effecten Van Peoplemanagement. Utrecht: Utrecht University.

Lance, C. E., B. Dawson, D. Birkelbach, and B. J. Hoffman. 2010. "Method Effects, Measurement Error, and Substantive Conclusions." Organizational Research Methods 13 (3): $435-455$.

Lee, G., J. Benoit-Bryan, and T. P. Johnson. 2012. "Survey Research in Public Administration: Assessing Mainstream Journals with a Total Survey Error Framework." Public Administration Review.

Liden, R. C., R. T. Sparrowe, and S. J. Wayne. 1997. "Leader-Member Exchange Theory: The Past and Potential for the Future." In Research in Personnel and Human Resource Management, edited by G. R. Ferris. Vol. 15, 47-119. Greenwich: Elsevier Science/JAI Press.

Liden, R. C., S. J. Wayne, and R. T. Sparrowe. 2000. "An Examination of the Mediating Role of Psychological Empowerment on the Relations between the Job, Interpersonal Relationships, and Work Outcomes." Journal of Applied Psychology 85 (3): 407-416.

Liden, R. C., S. J. Wayne, and D. Stilwell. 1993. "A Longitudinal Study on the Early Development of Leader-Member Exchanges." Journal of Applied Psychology 78 (4): 662-674. 
Marx, K. 1961 [1844]. "Alienated Labor." In Economic and Philosophic Manuscripts of 1844, edited by K. Marx, 67-83. Moscow: Foreign Languages Publishing House.

May, D. R., R. L. Gilson, and L. M. Harter. 2004. "The Psychological Conditions of Meaningfulness, Safety and Availability and the Engagement of the Human Spirit at Work." Journal of Occupational and Organizational Psychology 77 (1): 11-37.

Maynard, M. Travis, Lucy L. Gilson, and John E. Mathieu. 2012. "Empowerment-—Fad Or Fab? A Multilevel Review of the Past Two Decades of Research." Journal of Management 38 (4): 1231-1281.

McAllister, D. J. 1995. "Affect-and Cognition-Based Trust as Foundations for Interpersonal Cooperation in Organizations." The Academy of Management Journal 38 (1): 24-59.

Meyer, J. P., D. J. Stanley, L. Herscovitch, and L. Topolnytsky. 2002. "Affective, Continuance, and Normative Commitment to the Organization: A Meta-Analysis of Antecedents, Correlates, and Consequences." Journal of Vocational Behavior 61 (1): 2052.

Ministry of the Interior. 2010. "Kerngegevens Personeel Overheid En Onderwijs 2010." http://www.arbeidenoverheid.nl/media/81234/publicatie\%20kg\%202010.pdf (Visited July 1, 2012).

Mintzberg, Henry. 1998. "Covert Leadership: Notes on Managing Professionals." Harvard Business Review 76: 140-148.

Mottaz, C. J. 1981. "Some Determinants of Work Alienation." Sociological Quarterly 22 (4): 515-529. 
Muthén, LK and BO Muthén. 1998-2010. Mplus User's Guide. Sixth ed. Vol. 3. Los Angeles, CA: Muthén \& Muthén.

Olivier, AL and S. Rothmann. 2007. "Antecedents of Work Engagement in a Multinational Oil Company." SA Journal of Industrial Psychology 33 (3): 49-56.

Pandey, S. K., D. H. Coursey, and D. P. Moynihan. 2007. "Organizational Effectiveness and Bureaucratic Red Tape." Public Performance \& Management Review 30 (3): 398-425.

Perry, J. L. 2012. "How can we Improve our Science to Generate More Usable Knowledge for Public Professionals?" Public Administration Review 72 (4): 479-482.

Perry, J. L. and A. Hondeghem. 2008. Motivation in Public Management: The Call of Public Service. Oxford: Oxford University Press.

Pierce, J. L. and R. B. Dunham. 1987. "Organizational Commitment: Pre-Employment Propensity and Initial Work Experiences." Journal of Management 13 (1): 163-178.

Podsakoff, P. M., S. B. MacKenzie, J. Y. Lee, and N. P. Podsakoff. 2003. "Common Method Biases in Behavioral Research: A Critical Review of the Literature and Recommended Remedies." Journal of Applied Psychology 88 (5): 879-903.

Rainey, H. G. and B. Bozeman. 2000. "Comparing Public and Private Organizations: Empirical Research and the Power of the a Priori." Journal of Public Administration Research and Theory 10 (2): 447-470.

Rainey, H. G. and P. Steinbauer. 1999. "Galloping Elephants: Developing Elements of a Theory of Effective Government Organizations." Journal of Public Administration Research and Theory 9 (1): 32. 
Schaufeli, Wilmar B., Isabel M. Martínez, Alexandra Marques Pinto, Marisa Salanova, and Arnold B. Bakker. 2002. "Burnout and Engagement in University Students a CrossNational Study." Journal of Cross-Cultural Psychology 33 (5): 464-481.

Seeman, M. 1959. "On the Meaning of Alienation." American Sociological Review 24 (6): 783-791.

Spreitzer, G. M. 1995. "Psychological Empowerment in the Workplace: Dimensions, Measurement, and Validation." Academy of Management Journal (5): 1442-1465.

Terry, L. D. 2002. Leadership of Public Bureaucracies: The Administrator as Conservator. San Francisco: ME Sharpe Inc.

Trottier, T., M. Van Wart, and X. H. Wang. 2008. "Examining the Nature and Significance of Leadership in Government Organizations." Public Administration Review 68 (2): 319333.

Tummers, L. G. 2011. "Explaining the Willingness of Public Professionals to Implement New Policies: A Policy Alienation Framework." International Review of Administrative Sciences 77 (3): 555-581.

Tummers, L. G. and V. J. J. M. Bekkers. forthcoming. "Policy Implementation, Street-Level Bureaucracy and the Importance of Discretion." Public Management Review: 1-27.

Van Wart, M. 2013. "Administrative Leadership Theory: A Reassessment After 10 Years." Public Administration Early View. 
Vandenabeele, Wouter. 2008. "Government Calling: Public Service Motivation as an Element in Selecting Government as an Employer of Choice." Public Administration 86 (4): 1089-1105.

Wang, H., K. S. Law, R. D. Hackett, D. Wang, and Z. X. Chen. 2005. "Leader-Member Exchange as a Mediator of the Relationship between Transformational Leadership and Followers' Performance and Organizational Citizenship Behavior." The Academy of Management Journal: 420-432.

Wright, B. E., D. P. Moynihan, and S. K. Pandey. 2012. "Pulling the Levers: Transformational Leadership, Public Service Motivation, and Mission Valence." Public Administration Review 72 (2): 206-215.

Wright, B. E. and S. K. Pandey. 2010. "Transformational Leadership in the Public Sector: Does Structure Matter?" Journal of Public Administration Research and Theory 20 (1): 75-89.

Zaleznik, A. 1977. "Managers and Leaders: Are they Different?" Harvard Business Review May/June: 67-78. 